\title{
PENDAMPINGAN USAHA KERIPIK TORTILLA JAGUNG PADA KELOMPOK WANITA TANI
}

\section{ASSISTANCE IN BUSINESS PRODUCTION OF CORN TORTILLA CHIPS IN A GROUP OF WOMEN FARMERS}

\author{
${ }^{1)}$ Siti Nurdjanah, ${ }^{2)}$ Sri Setyani, ${ }^{3)}$ Wisnu Satyajaya, ${ }^{4)}$ din Hasanudin \\ 1,2,3,4)Jurusan Teknologi Hasil Pertanian Fakultas Pertanian Universitas Lampung \\ Jalan Soemantri Brojonegoro No 1, Bandar Lampung 35145 \\ email: siti.nurdjanah@fp.unila.ac.id
}

\begin{abstract}
ABSTRAK
Tujuan dari kegiatan ini adalah membantu meningkatkan kapasitas produksi, kualitas dan jangkauan pemasaran produk keripik tortilla jagung khas Lampung Selatanagar beromsetinggi dan memberikan lapangan kerja yang lebih banyak. Metode yang digunakan adalah ceramah dan praktek pelatihan tentang pascapanen, pengolahan serta pengemasan yang sesuai dengan persyaratan Good Manufacturing Practice, serta pengawasan mutu produk dan pembukuan.Hasilyang dicapai oleh Unit Usaha Kelompok Wanita Tani Kemuning II Lampung Selatan antara lain telah mengalami peningkatan aset sebesar 10\%, peningkatan omset menjadi dua kali, kualitas produk tortilla lebih renyah dan ditambah variasi rasa berbagai rasa dan peningkatan jangkauan pemasaran sampai ke Bandar Lampung.
\end{abstract}

Kata kunci : Jagung, Kelompok Wanita Tani, Tortilla

\section{ABSTRACT}

The purpose of this program was to help increase the production capacity, quality and marketing area of South Lampung corn tortilla chips so that they have a high turnover and provide more employment opportunities. The methods used were lectures and training practices on postharvest, processing and packaging that are in accordance with the requirements of Good Manufacturing Practice. Other trainings given were product quality and bookkeeping. The results achieved by the Kemuning II South Lampung Women's Farmers' Business Unit, were an increase in assets of 10\%, an increase in turnover to twice, the quality of tortilla products is crisper and a variety of flavors and increased marketing range reaching Bandar Lampung areas

Keywords: Corn, Farmer Women Group, Tortillas

Submited : 11 Juli $2018 \quad$ Revision : 11 Desember $2018 \quad$ Accepted : 26 Desember 2018

\section{PENDAHULUAN}

Jagung memiliki komponen
yang berperan penting pada perkembangan industry pangan dan pakan ternak. Komponen utama jagung adalah pati, yaitu sekitar $70 \%$ dari bobot biji. Komponen karbohidrat lain adalah gula sederhana, yaitu glukosa, sukrosa dan fruktosa,1-3\% dari bobot biji. Pati jagung terdiri dari beberapa tempat seperti endosperma $(84,4 \%)$, lembaga $(8,2 \%)$ dan tudung biji $(5,3 \%)$. Protein jagung terdapat dalam lembaga $(8,5 \%)$ dan endosperma $(8,6 \%)$. Asam lemak essensial berupa asam linolenat, asam linoleat dan asam oleat berturut-turut adalah 59\%, 0,8\%, 27\% dari total kandungan lemak biji jagung (Suarni and Widowati, 2007). 
Pemanfaatan jagung sebagai bahan baku industry pangan /ternak akan memberikan nilai positif bagi komoditas jagung.

Propinsi Lampung merupakan sentra komoditas jagung yang tersebar di berbagai kabupaten, diantaranya Kabuptaen Lampung Selatan. Di Lampung Selatan terdapat beberapa kelompok tani diantaranya adalah Kelompok Wanita Tani Kemuning II. KWT ini merupakan salah satu kelompok yang memilki usaha dalam bidang pengolahan hasil hortikultura dan tanaman pangan terutama jagung. Kelompok tani di sekitar KWT Kemuning II terutama Kelompok Tani Rejosari II juga menghasilkan sekitar 600 ton/tahun. Hampir semua produksi jagung pada kelompok tani Rejosari II hanya dimanfaatkan biji jagungnya dan dijual dalam bentuk jagung pipil kering sebagai bahan pakan ternak. Keadaan ini dimanfaatkan oleh anggota KWT Kemuning II untuk mendiversifikasikan produk olahan jagung dengan meproduksinya menjadi keripik tortilla. Keripik tortilla adalah makanan camilan favorit di amerika Latin, dibuat dari bahan bau jagung yang sudah dinixtamalisasi atau direndam dalam air kapur dan direbus terlebih dahulu, kemudian dipanggang dan digoreng (Saldivar dkk., 1990; Dedeh dkk., 2004).

Akan tetapi usaha keipik tortilla KWT Kemuning II masih mengalami kendala antara lain dalam bidang teknik pengolahan yang higenis, kualitas yang belum konsisten, pembukuan dan pemasaran. Oleh karena itu tujuan kegiatan ini adalah untuk melakukan pendampingan kepada unit usaha tortilla sehingga kapasitas produksi, kualitas dan jangkauan pemasaran meningkat, serta sistem pembukuan yang baik.
Metode yang digunakan dalam kegiatan ini adalah :

1. Ceramah tentang pentingnya
penanganan pasca panen, dan
pengawasan mutu untuk tujuan
pemasaran, GMP, HACCP.
2. Ceramah tentang pengelolaan usaha

2. Ceramah tentang pengelolaan usaha yang sehat (pembukuan, pemasaran dan K-3).

3. Pelatihan tentang pembuatan keripik tortilla jagung yang lebih efesien dan lebih higienis(Diagram alir proses pembuatan tortilla disajikan pada Gambar 3), serta pelatihan pengoperasian peralatan.

4. Pendampingan produksi dari tahap uji coba sampai produksi komersial

\section{HASIL DAN PEMBAHASAN}

KWT Kemuning II telah mengetahui dan memahami cara cara mengelola usaha produksi tortilla dengan baik. Pengetahuan dan pemahaman tersebut meliputi cara penerapan Good Manufacturing Practises, pengemasan dan penyimpanan bahan baku maupun bahan olahan (tortilla), pemasaran, sistem pembukuan serta perolehan legalitas (PIRT). Oleh karena itu KWT telah melakukan proses roduksi tortillamelakukan pengolahan produk dan memasarkannya dengan rutin. Setelah diperolehnya PIRT, kami Tim dari Unila mencoba membantu memperluas jangkauan pemasaran produk untuk dipasarkan di minimarket (pasar non tradisional).Ada beberapa minimarket yang sudah mau menerima produk KWT baik minimarket di Kalianda maupun Bandar Lampung dan beberapa minimarket lainnya sedang dalam penjajagan. Sementara itu penggunaan sarana internet untuk promosi produk (internet marketing) juga sedang dirancang dengan tujuan agar produk bisa dikenal masyarakat lebih luas dan calon pembeli bisa pesan produk secara langsung (online).

\section{METODE}


Siti Nurdjanah, Sri Setyani, Wisnu Satyajaya, Udin Hasanudin

Pendampingan Usaha Keripik Tortilla Jagung Pada Kelompok Wanita Tani

\begin{abstract}
Pemasaran atau promosi menggunakan media internet berbeda dengan mass marketing dan direct marketing yang biasanya bersifat pasif (pemberian informasi satu arah), sifat internet marketing ini adalah aktif atau dengan kata lain, Internet marketing mempunyai keunggulan karena memungkinkan konsumen berinteraksi dengan perusahaan emasar melalui iklan. Sebagai contoh, iklan persegi panjang (banner) yang dipasang pada situs pencari yang terhubung (di-link) dengan situs penjual atau katalog penjual sehingga konsumen dapat langsung berkomunikasi dengan penjual hanya dengan nenekan tombol iklan tersebut (Cahyadi, 2005)
\end{abstract}

Selain dilakukan pendampingan rutin, baik secara langsung maupun secara komunikasi jarak jauh (WA, SMS dan email) juga dilakukan pelatihan/diskusi interaktif serta konsultasi tentang perkembangan usaha dan pengelolaannya.Meskipun pelatihan penggunaan extruder sudah dilakukan, sementara masih belum bisa dioperasikan secara optimal. Hal ini disebabkan oleh karena anggota KWTbelum benar benar memahami proses pengoperasian alat sehingga masih memerlukan uji coba berulang ulang sehingga mereka menguasi dan alat dapat dioperasikan secara optimal. Kedepannya, setelah mesin extruder dan mesin kemasan otomatis sudah beropersi secara optimal, maka produk yang dihasilkan lebih menarik dan lebih higenis serta volume produksi lebih meningkat serta diperolehnya ijin PIRT, diharapkan jangkauan pemasaran akan meluas baik di pasar tradisional maupun pasar non tradisional (minimarket) di Lampung.

Penggunaan extruder sebagai pengembangan usaha tortilla merupakan hal penting yang harus dipertimbangkan. Hal ini disebabkan oleh kemampuan extruder menghasilkan snack jagung siap makan tanpa proses penggorengan terlebih dahulu sehingga produk lebih tahan terhadap reaksi ketengikan (akibat oksidasi lemak), lebih sehat karena rendah lemak, serta kapasitas produksi yang besar. Proses pemasakan ekstrusi memerlukan waktu singkat dengan suhu tinggi (HTST). Pemanasan dicapai melalui geseran dan gesekanulir di dalam extruder. Teknologi ini memiliki banyak keunggulan seperti biaya rendah, kualitas produk yang lebih baik dan tidak ada meninggalkan limbah (Sobowale dkk., 2017).

Keberhasilan Unit Usaha KWT
Kemuning dalam mengelola usaha
pengolahan hasil hortikultura terutama
keripik tortilla dan abon cabe tidak hanya
tergantung oleh danayang diperoleh dari
pihak luar atau pendamping dari Tim
Pengabdian Kepada Masyarakat dari
Universitas Lampung. Akan tetapi
keberhasilan sangat tergantung dari
kemauan dan kemampuan serta
kesungguhan para anggota untuk
mengelola usaha dengan baik. Oleh karena
itu semua anggota harus selalu bekerja
sama dalam memajukan unit usaha. Selain
itu Good Manufacturing Practices (Cara-
Cara Pengolahan Yang Baik) harus selalu
menjadi acuan dalam memproduksi tortilla
yang berkualitas, sehat, aman dan layak
dikonsumsi.

Keberadaan mesin extruder diharapkan segera dimanfaatkan agar kapasitas produksi meningkat berlipat, sehingga unit usaha akan lebih jelas eksistensinya, dapat meningkatkan sumberdaya manusia yang terlibat secara aktif dari bidang penyediaan bahan baku, penngolah dan pemasaran. Lebih lanjut pengelolaan sistem administrasi dan keuangan harus dikelola dengan baik karena hal ini juga merupakan kunci utama keberhasilan usaha, agar kedepan akan lebih maju lagi. Selain kendala di bidang pemasaran (Satyajaya dkk., 2017), secara umum, pada tahun 2017 usaha tortilla telah mengalami kenaikan produksi. Selama tahun 2016 produksi masih berfluktuasi dengan rata rata produksi $5 \mathrm{~kg}$ tortilla kering mentah per hari, akan tetapi 10 bulan terakhir pada tahun 2017 ini 
produksi sudah dilakukan secara rutin dengan jumlah produksi rata rata tiap hari sebesar $10 \mathrm{~kg}$ keripik tortilla kering mentah

Jenis jagung yang digunakan sebagai bahan baku dalam memproduksi keripiktortilla adalah jagung mutiara (jagung kuning). Karena jenis jagung ini dominan yang ditanam di Lampung Selatan. Jagung jenis kuning ini mempunyai sifat - sifat yang lebih baik dari jenis jagung lainnya, dengan hasil produksi yang jauh lebih tinggi (Kolo dan Hutappea, 2016). Warna jagung yang dominan kuning sangat cocok digunakan sebagai bahan baku tortilla karena menyebabkan keripik tortilla berwarna kuning cerah yang disukai konsumen.

Satyajaya dkk (2017) menyatakan bahwa berdasarkan hasil perhitungan (Total attractive Score (TAS) dari matrik Quantitative Strategic Planning Matrix (QSPM) (David,2009), strategi yang paling diminati dan diprioritaskan untuk dilakukan oleh usaha Kemuning II yaitu memperbaiki sistem manajemen internal dan perbaikan produk untuk meningkatkan motivasi dan semangat kerja dengan skor TAS sebesar. Dalam QSPM, strategi yang mendapat total attractive score tertinggi merupakan strategi utama yang paling mungkin untuk dilakukan dalam usaha (Budiasih dkk., 2014). Alternatif strategi tersebut lebih diperioritaskan dikarenakan selama ini sistem manajemen internal yang dilakukan belum berjalan dengan baik.

\section{SIMPULAN}

Unit usaha produksi keripik tortilla yang dikelola oleh Kelompok Wanita Tani Kemuning desa Marga Catur Kecamatan Kalianda Lampung Selatan telah dibina dan didampingi oleh Tim Pengabdian Kepada Masyarakat Universitas Lampung sehingga mengalami kemajuan.Sistem GMP telah dilaksanakan dengan baik, ruang ruang produksi telah ditata sehingga higenitas produk dan sanitasi ruang produksi terjaga.Produksi sudah dilakukan secara rutin sehingga volume produksi sudah mengalami peningkatan serta omset penjualan tunai sudah meningkat dari 5 $\mathrm{kg} / \mathrm{hari}$ menjadi sekitar $10 \mathrm{~kg} / \mathrm{hari}$. Sistem pengelolaan juga sudah meningkat lebih teratur sehingga dokumen sudah tertata denga rapi, baik pembukuan atau pencataan tentang produksi maupun system keuangan sudah dilakukan dengan rapi dan benar sesuai standar.Unit usaha juga telah berhasil menciptakan lapangan pekerjaan baik bagi para anggotanya yang aktif dan rutin memproduksi tortilla maupun bagi masyarakat sekitar yang bukan anggota tetapi aktif memasarkan produk.Kedepan diharapkan usaha ini lebih berkembang dan dapat memberikan efek yang lebih signifikan dibidang ekonomi.

\section{UCAPAN TERIMAKASIH}

Ucapan Terimaksih disampaikan kepada DPRM Kemenristek DIKTI atas dana yang diberikan untuk dilaksanakannya kegiatan ini dengan Nomor Kontrak : 549/UN.26.21/KU/2017

\section{DAFTAR PUSTAKA}

Budasih, N.L., Ambarawati, I.G.A.A dan Astiti, N.W.S. (2014). Strategi pemasaran produk olahan jamur tiram pada kelompok wanita tani (KWT) Spora Bali. J. Manajemen Agribisnis. 2(2), 114-130.

Cahyadi, A. (2005). Internet Marketing: Solusi Bagi Pengusaha Bermodal Kecil, Journal The WINNERS, 6 (1), 23-32.

David, F. R. ( 2009). Manajemen Strategis. Salemba Empat, Jakarta.

Dedeh, S., B. Cornelius, E. SakyiDawson, andE.O. Afoakwa.( 2004). Eff ect of nixtamalization on the chemical and functional properties of maize. Food Chemistry, 86, 317-324.

Kolo, D., dan A. N. Hutapea. (2016). Strategi Pengembangan Usaha Biskuit 


\begin{abstract}
Jagung Di Kelompok Wanita Tani Lestari Desa Subun Tua'lele Kecamatan Insana Barat Kabupaten Timor Tengah Utara. Agrimor, 1 (3): 42-45
\end{abstract}

Satyajaya, W., A. Rangga, M. Marniza, I.M.Alfian.(2017). Strategi Pemasaran Produk Tortilla Jagung (Studi Kasus UMKM Kelompok Wanita Tani Kemuning II Desa Marga Catur, Kalianda). J.Fd.Life.Sci. 1 (1), $11-20$. doi: 10.21776/ub.jfls.2017.001.01.02

Saldivar, S.O., M.H.Gomez, and L.W. Rooney. (1990). "Technology, chemistry, and nutritional value of alkaline-cooked corn products". In Advances in Cereal Science and Technology; Pomeranz, Y, 243St. Paul, MN: American Assoc. Cereal Chemists.

Sobowale,S.S., A. Bamgbose.A.S. Adeboye.(2016) Effect of Extrusion Variables on the Extrudate Properties of Wheat-plantain Noodle. J Food Process Technol 7: 547. doi:10.4172/21577110.1000547

Suarni dan S. Widowati.(2007). Struktur, Komposisi, Dan Nutrisi Jagung. Pusat Penelitian Tanaman Pangan, Bogor. hlm. 410-426. 